\title{
UKURAN PERTAMA KALI MATANG GONAD UDANG Penaeus merguiensis De Man (1988) DI LAUT ARAFURA PADA DISTRIK NAUKENJERAI KABUPATEN MERAUKE
}

\author{
Edy H. P. Melmambbessy \\ Staf Pengajar UNIMER-Merauke, $\boldsymbol{e}$-mail: -
}

\begin{abstract}
ABSTRAK
Penelitian ini bertujuan untuk menganalisis ukuran pertama kali matang gonad udang Penaeus merguiensis di Distrik Naukenjerai Kabupaten Merauke. Sedangkan kegunaannya adalah sebagai bahan informasi ilmiah untuk kepentingan pengelolaan perikanan udang secara berkelanjutan. Metode yang digunakan adalah metode survei, lokasi penelitian : Distrik Naukenjerai Kabupaten Merauke. Penelitian berlangsung pada bulan Maret - Mei 2011. Analisa data meliputi : perkembangan gonad, ukuran pertama kali matang gonad dan struktur ukuran panjang karapas. Hasil penelitian yang diperoleh adalah (1) ukuran pertama kali matang gonad udang Penaeus merguiensis di perairan Distrik Naukenjerai, berada pada kisaran panjang karapas 64,44 mm untuk jantan dan 58,37mm - 60,26 mm untuk betina. Untuk bobot, udang Penaeus merguiensis mencapai ukuran pertama matang gonad pada kisaran 31,24 gr untuk jantan dan 16,93 gr - 17,66 gr untuk betina. (2) ukuran udang yang tertangkap didominasi oleh ukuran yang belum matang gonad, yaitu udang dengan panjang karapas 26,5 mm. Untuk kepentingan pengelolaan perikanan udang Penaeus merguiensis di perairan laut Arafura pada Distrik Naukenjerai, maka diperlukan upaya pengaturan ukuran mata jaring dari $10 \mathrm{~mm}$ menjadi $25,40 \mathrm{~mm}$ dan sosialisasi aturan dan pengawasan di lapangan.
\end{abstract}

\section{Kata Kunci: Matang gonad, Penaeus merguiensis, Kabupaten Merauke}

\section{PENDAHULUAN}

\subsection{Latar Belakang}

Pengelolaan perikanan (fisheries management) merupakan proses yang kompleks, memerlukan integrasi faktor-faktor : biologi, ekologi, sosial budaya dan kelembagaan, ekonomi serta faktor teknologi berpengaruh terhadap perilaku nelayan dan pengambil kebijakan. Tujuan pengelolaan adalah terwujudnya kelestarian sumberdaya ikan agar dapat dinikmati oleh generasi mendatang.

Dengan hadirnya Undang-Undang Nomor 21 Tahun 2001 tentang Otonomi Khusus Papua dimana Pembangunan di Propinsi Papua dilakukan dengan berpedoman pada prinsipprinsip pembangunan berkelanjutan, pelestarian lingkungan, manfaat, dan keadilan dengan memperhatikan rencana tata ruang wilayah.

Kabupaten Merauke Propinsi Papua memiliki sumberdaya udang yang cukup potensial, hal ini dikarenakan hutan mangrove yang terdapat di sepanjang pesisir pantai masih terawat relatif cukup baik dan terjaga kelestariannya. Jenis udang yang menjadi target utama penangkapan pada daerah ini adalah jenis udang yang termasuk dalam genera Penaeus dan Metapenaeus seperti : udang Penaeus merguiensis, Penaeus monodon dan Metapenaeus endeavouri. Dari ketiga spesies udang ini, jenis dominan yang tertangkap adalah udang Penaeus merguiensis (Dinas Kelautan dan Perikanan - DKP Kabupaten Merauke, 2010).

Distrik Naukenjerai adalah merupakan sentra penangkapan udang Penaeus merguiensis di Kabupaten Merauke. Penangkapan udang Penaeus merguiensis di daerah ini biasanya dilakukan oleh nelayan dengan menggunakan alat penangkapan pukat tarik dan jaring insang. Ukuran mata jaring pukat tarik adalah 10 - 25 $\mathrm{mm}$, sedangkan ukuran mata jaring insang adalah 25 - $35 \mathrm{~mm}$. Pada bulan Maret - Mei 2011, para nelayan hanya menggunakan pukat 
tarik untuk menangkap udang Penaeus merguiensis karena jaring insang digunakan untuk menangkap udang, jika tiba waktunya penangkapan udang yang berukuran super pada bulan Juni - Agustus setiap tahunnya. Ukuran mata jaring pukat tarik tidak sesuai dengan standar Nasional Peraturan Menteri Kelautan dan Perikanan Nomor : Per.02/Men/2011. Untuk itu perlu dilakukan penelitian untuk menganalisis ukuran pertama kali matang gonad, agar menjadi acuan didalam pengelolaan perikanan tangkap udang Penaeus merguiensis di Distrik Naukenjerai Kabupaten Merauke.

\subsection{Tujuan dan Manfaat Penelitian}

Penelitian ini bertujuan untuk menganalisis ukuran pertama kali matang gonad udang Penaeus merguiensis di Distrik Naukenjerai Kabupaten Merauke. Sedangkan kegunannya adalah sebagai bahan informasi ilmiah untuk kepentingan pengelolaan perikanan udang secara berlelanjutan.

\section{METODE PENELITIAN}

\subsection{Lokasi dan Waktu}

Penelitian ini dilaksanakan di Perairan laut Arafura pada Wilayah otonom Kabupaten Merauke tepatnya pada tiga kampung di Distrik Naukenjerai, yaitu 1) Kampung Ndalir, Kampung Kuller dan Kampung Onggaya. (Gambar 1).
Penelitian dilaksanakan selama 3 bulan yaitu Maret - Mei 2011.

\subsection{Metode Pengumpulan Data}

Metode penelitian yang digunakan adalah metode survey (Nasir, 2003). Data primer berupa udang penaeid sebagai sampel diperoleh dari nelayan setelah melaut, dengan alat tangkap pukat tarik (mesh size $10 \mathrm{~mm}$ dan $25 \mathrm{~mm}$ ) sebanyak 2-3 kg. Pengambilan sampel dilakukan dua kali dalam seminggu (selasa, dan kamis) pada ketiga kampung pengamatan mulai bulan Maret sampai Mei 2011, sehingga jumlah sampel sebanyak 2 x 10 minggu $=20$ kali. Sampel udang penaeid yang diperoleh dari ketiga kampung pengamatan dimasukkan ke cool box (polar cooler kapasitas 8 liter) dan dibawakan ke laboratorium Fakultas Pertanian Universitas Musamus Merauke untuk keperluan : identifikasi, pengukuran panjang (panjang total dan panjang karapas), pengukuran berat dan pengamatan TKG udang $P$. merguiensis. Setelah itu sampel gonad udang $P$. merguiensis diambil mewakili masingmasing stage (I-IV) sebanyak 3 sampel, sehingga total sampel 12. Sampel-sampel ini diawetkan dengan larutan buffer neutral formalin (BNF) $10 \%$, kemudian dianalisis histolonya di Balai Veteriner Maros Propinsi Sulawesi Selatan.

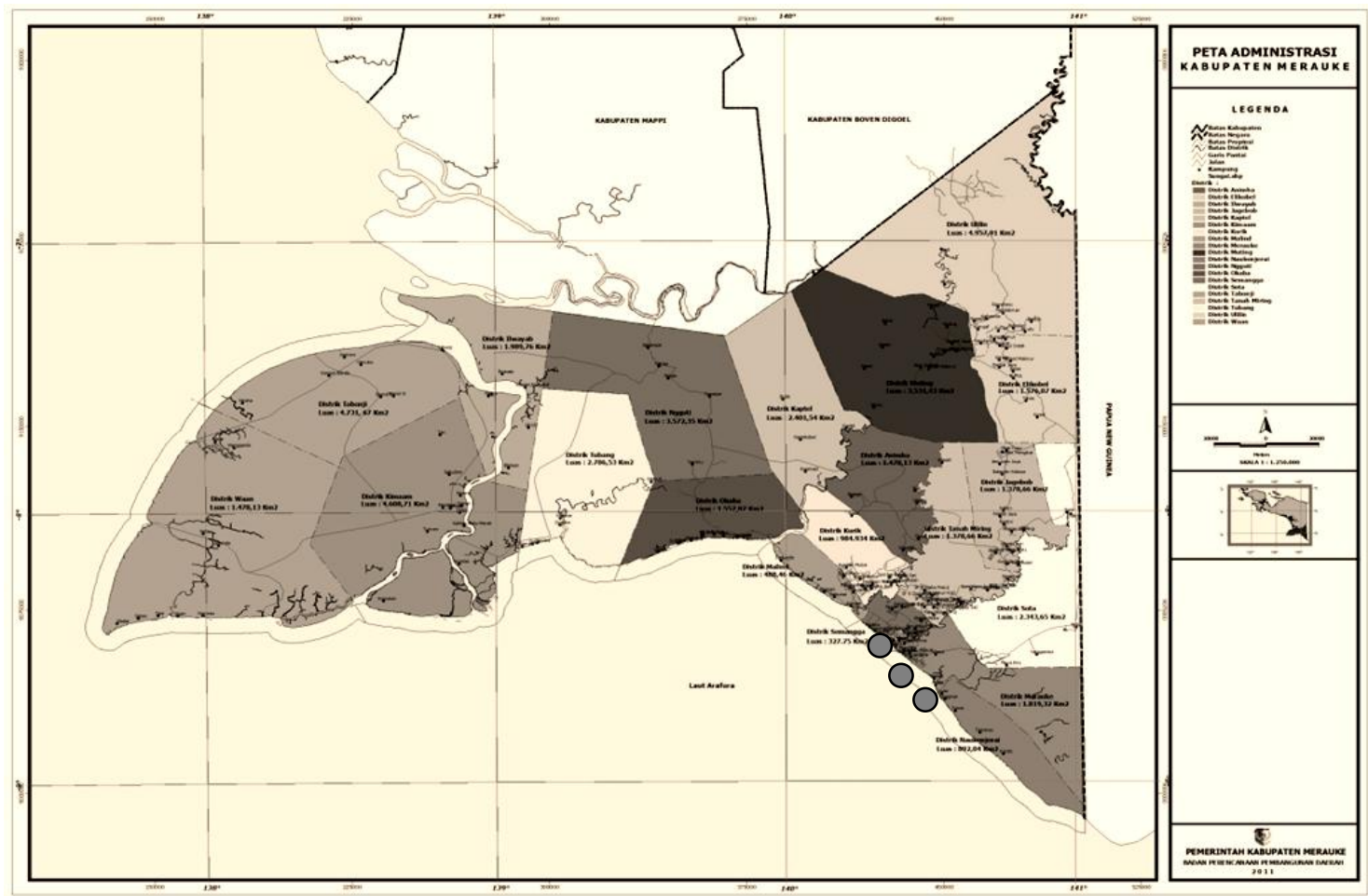

Gambar 1. Peta Lokasi Penelitian 


\subsection{Analisa Data}

\subsubsection{Perkembangan Gonad}

Perkembangan

P.merguiensis, diamati gonad morfologi mengacu pada Motoh (1981) tingk kematangan gonad udang $P$. merguiensis berlangsung dalam lima tahap seperti pada Gambar 2, dimana ciri-ciri secara morfologi yaitu :

Tahap 1 : belum matang, - ovari tipis, bening dan tidak berwarna;

Tahap 2 : kematangan awal - ovari membesar dan bagian tengah dan depan berkembang;

Tahap 3 : kematangan lanjut - ovari berwarna hijau muda dan dapat dilihat melalui eksoskeleton, bagian tengah dan depan berkembang penuh;

Tahap 4 : matang telur /kematangan akhir ovari berwarna hijau tua, ova lebih besar dari tingkat sebelumnya, dan

Tahap 5 : sesudah bertelur/spent - ovari lembek dan lebih kuat, ova sudah dilepas.

Setelah pengamatan secara morfologi, dilanjutkan dengan pengamatan histologi untuk memastikan bahwa tahap kematangan gonad Penaeus merguiensis yang telah dilakukan secara morfologi sudah tepat. Pengamatan histologi mengacu pada Ayub dan Ahmed (2002) dan Wonglapsuwan at all., (2010). Penyajian TKG udang $P$. merguiensis dilakukan dengan metode histogram. Histogram adalah grafik yang menggambarkan distribusi frekuensi dengan bentuk beberapa segi empat (Riduwan, 2009).

\subsubsection{Ukuran Pertama Kali Matang Gonad}

Untuk mengetahui ukuran pertama matang gonad dilakukan sesuai dengan metode Spearmen-Karber (Udupa, 1986) sebagai berikut :

$$
\mathrm{m}=\mathrm{Xk}+\frac{X}{2}-(\mathrm{X} \Sigma \mathrm{pi})
$$

Jika $\propto=0,05$, maka batas-batas kepercayaan 95\% dari m adalah :

$$
\operatorname{antilog}\left[\mathrm{m} \pm 1,96 \sqrt{ } \mathrm{X}^{\left.\left.2 \sum \notin \frac{p i x q i}{n i-1}\right)\right] \ldots \ldots}\right.
$$

dimana, m merupakan logaritma panjang pada saat pertama kali matang gonad, xk merupakan logaritma nilai tengah kelas panjang pada saat $100 \%$ matang gonad, X merupakan selisih logaritma nilai tengah, pi merupakan proporsi matang gonad pada kelas ke-i $(\mathrm{pi}=\mathrm{ri} / \mathrm{ni})$, ri merupakan jumlah matang gonad pada kelas ke-i, ni merupakan jumlah pada kelas ke-i dan qi adalah 1-pi. Dengan demikian rata-rata panjang karapas Penaeus merguiensis pada waktu mencapi kematangan gonad pertama kali adalah $\mathrm{M}=$ antilog $\mathrm{m}$.

\subsubsection{Struktur ukuran}

Komposisi ukuran panjang karapaks dan ukuran berat dianalisis secara deskriptif dalam grafik histogram dengan satuan prosentase.

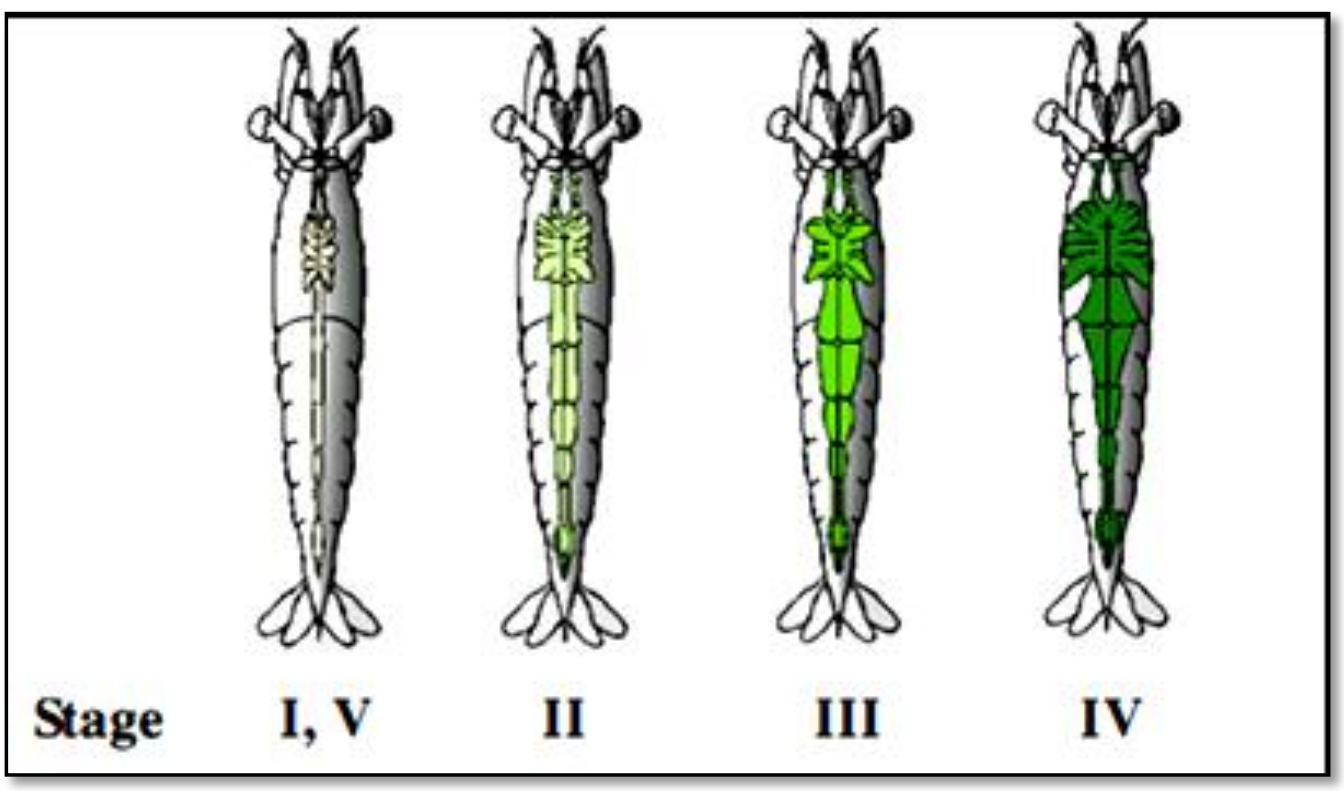

Gambar 2. Tahapan tingkat kematangan gonad (Trece, 2005) 


\section{HASIL DAN PEMBAHASAN \\ 3.1 Perkembangan Gonad}

Perkembangan gonad pada udang Penaeus merguiensis selama penelitian berlangsung berada dalam empat tahap, dimana ciri-ciri secara morfologinya adalah : (1) belum matang, - ovari tipis, bening dan tidak berwarna; (2) kematangan awal - ovari membesar dan bagian tengah dan depan berkembang; (3) kematangan lanjut - ovari berwarna hijau muda dan dapat dilihat melalui eksoskeleton, bagian tengah dan depan berkembang penuh; (4) matang telur/kematangan akhir - ovari berwarna hijau tua, ova lebih besar dari tingkat sebelumnya. Belum ditemukannya TKG V pada saat penelitian karena pada tingkatan ini prosesnya berlangsung begitu cepat. Untuk keperluan histologi, maka prosedur operasional dilakukan pada sampel gonad udang P. merguiensis, termasuk pewarnaan. Sebelum pewarnaan dilakukan, semua bahan pewarna harus diperiksa kejernihannya dan disesuaikan dengan jadwal penggantian yang tersedia (3 kali penggunaan setiap pemakaian). Pewarnaan menggunakan mayers hematoxylin eosin. Tahapan pewarnaan, seperti pada Tabel 1.

Tabel 1. Tahap Pewarnaan Mayers Hematoxylin Eosin

\begin{tabular}{|c|c|c|}
\hline No & Reagensia & Waktu \\
\hline 1 & Xylol I & 2 menit \\
\hline 2 & Xylol II & 2 menit \\
\hline 3 & Alkohol 100\% I & 1 menit \\
\hline 4 & Alkohol 100\% II & 1 menit \\
\hline 5 & Alkohol 95\% I & 1 menit \\
\hline 6 & Alkohol 95\% II & 1 menit \\
\hline 7 & Mayer's Haematoxylin & 15 menit \\
\hline 8 & Rendam dalam Tap Water & 20 menit \\
\hline 9 & Masukkan dalam Eosin & 15 detik -2 menit \\
\hline 10 & Alkohol $95 \%$ III & 2 menit \\
\hline 11 & Alkohol $95 \%$ IV & 2 menit \\
\hline 12 & Alkohol 100\% III & 2 menit \\
\hline 13 & Alkohol 100\% IV & 2 menit \\
\hline 14 & Akohol 100\%V & 2 menit \\
\hline 15 & Xylol III & 2 menit \\
\hline 16 & Xylol IV & 2 menit \\
\hline 17 & Xylol V & 2 menit \\
\hline
\end{tabular}

Perkembangan gonad secara histologi diperlukan untuk memastikan tahapan tingkat kematangan gonad yang ditentukan sudah tepat. Dan dari hasil histologi udang Penaeus merguiensis, dipastikan bahwa penentuan tahapan tingkat kematangan gonad selama penelitian sudah tepat.

Hasil histologi perkembangan gonad udang Penaeus merguiensis pada Gambar 3, dapat dijelaskan sesuai dengan Ayub dan Ahmed, (2002); dan Wonglapsuwan at all., (2010) bahwa bagian yang belum berkembang dari ovarium mengandung kromatin nukleolus dan oosit perinucleolar (PO). Untuk tingkat kematangan awal, perkembangan ovarium yang mengandung oosit perinucleolar (PO) dan kuning telur. Untuk tingkat kematangan lanjut, indung telur hampir matang menampilkan oosit yolky (YO). Dan pada tahap matang telur atau indung telur sudah masak menampilkan oosit dengan tubuh kortikal, perinucleolar oosit $(\mathrm{PO})$, oosit yolky $\left(\mathrm{YO}_{1}\right.$ dan $\mathrm{YO}_{2}$ ), CR, oosit dengan tubuh kortikal; sel-sel folikel (FC), nukleus (N).

\subsection{Ukuran pertama kali matang gonad}

Ukuran pertama kali kematangan gonad merupakan salah satu parameter penting dalam penentuan ukuran terkecil udang yang dapat ditangkap atau boleh ditangkap, baik jenis kelamin jantan ataupun betina.

Untuk wilayah perairan Distrik Naukenjerai, udang Penaeus merguiensis mencapai ukuran pertama kali matang gonad pada kisaran panjang karapas $64,44 \mathrm{~mm}$ untuk jantan dan 58,37mm - 60,26 mm untuk betina. Untuk bobot, udang Penaeus merguiensis mencapai ukuran pertama matang gonad pada kisaran 31,24 gr untuk jantan dan 16,93 - 17,66 gr untuk betina.

Berdasarkan perhitungan dengan menggunakan metode Spearman-Karber (Udupa, 1986) maupun berdasarkan ukuran pertama matang gonad sesungguhnya terlihat jelas bahwa individu betina mencapai ukuran pertama matang 
gonad lebih kecil dibandingkan dengan individu jantan pada wilayah perairan ketiga kampung. Perbedaan ukuran pertama matang gonad memperlihatkan adanya strategi reproduksi dari masing-masing spesies.

Struktur ukuran panjang karapas udang Penaeus merguiensis pada Distrik Naukenjerai seperti pada Gambar 4.

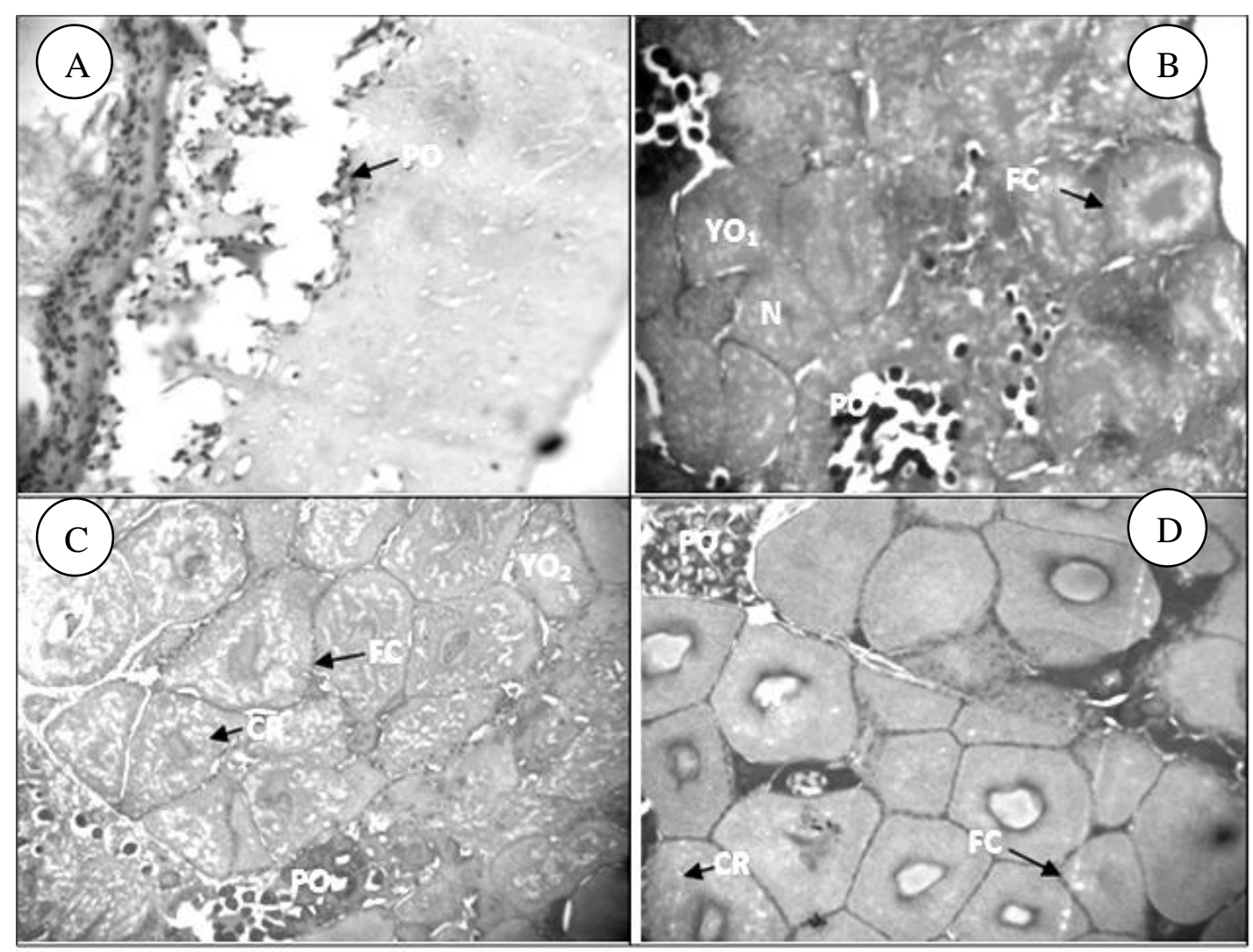

Gambar 3. A. Bagian yang belum berkembang dari ovarium yang mengandung kromatin nukleolus dan oosit perinucleolar. B perkembangan ovarium yang mengandung oosit perinucleolar dan kuning telur. $(C)$ indung telur hampir matang menampilkan oosit yolky. (D) indung telur sudah masak menampilkan oosit dengan tubuh kortikal., perinucleolar oosit (PO) ; oosit yolky (YO1), kuning telur (YO2); oosit dengan tubuh kortikal (CR); sel-sel folikel (FC), nukleus (N).

Komposisi ukuran merupakan pola ukuran panjang yang dibentuk oleh semua ukuran individu dalam suatu populasi, yang dikelompokan berdasarkan kelas ukuran panjang interval tertentu. Pola komposisi ukuran panjang karapas dari populasi udang Penaeus merguiensis adalah pola modus tunggal (komponen tunggal), dimana ukuran karapas yang memiliki frekuensi tertinggi dari sebaran ukuran panjang karapas udang yang ada pada ketiga distrik. Komponen tunggal dimaksud adalah pada ukuran panjang karapas 26,5 mm. Hal ini menunjukkan bahwa udang pada perairan Distrik Naukenjerai kebanyakan berada pada usia sebagai yuwana (juvenile) selama 2-3 bulan (Simon, at all., 2010) dimana pada fase tersebut ditemukan pada perairan dangkal dan pasang surut dari muara subtidal dan perairan pesisir (Dichmont 2006).

\section{PENUTUP}

\subsection{Kesimpulan}

1. Hasil analisis ukuran pertama kali matang gonad udang Penaeus merguiensis di wilayah perairan Distrik Naukenjerai, mencapai ukuran pertama kali matang gonad pada kisaran panjang karapas $64,44 \mathrm{~mm}$ untuk jantan dan 58,37mm - 60,26 mm untuk betina. Untuk bobot, udang Penaeus merguiensis mencapai ukuran pertama matang gonad pada kisaran 31,24 gr untuk jantan dan $16,93 \mathrm{gr}-17,66 \mathrm{gr}$ untuk betina.

2. Ukuran udang yang tertangkap didominasi oleh ukuran yang belum matang gonad, yaitu udang dengan panjang karapas 26,5 $\mathrm{mm}$. 


\subsection{Saran}

Untuk kepentingan pengelolaan perikanan udang Penaeus merguiensis di perairan laut Arafura pada Distrik Naukenjerai Kabupaten Merauke, diperlukan upaya :
1. Pengaturan ukuran mata jaring dari $10 \mathrm{~mm}$ menjadi $25,40 \mathrm{~mm}$.

2. Sosialisasi aturan dan pengawasan di lapangan.

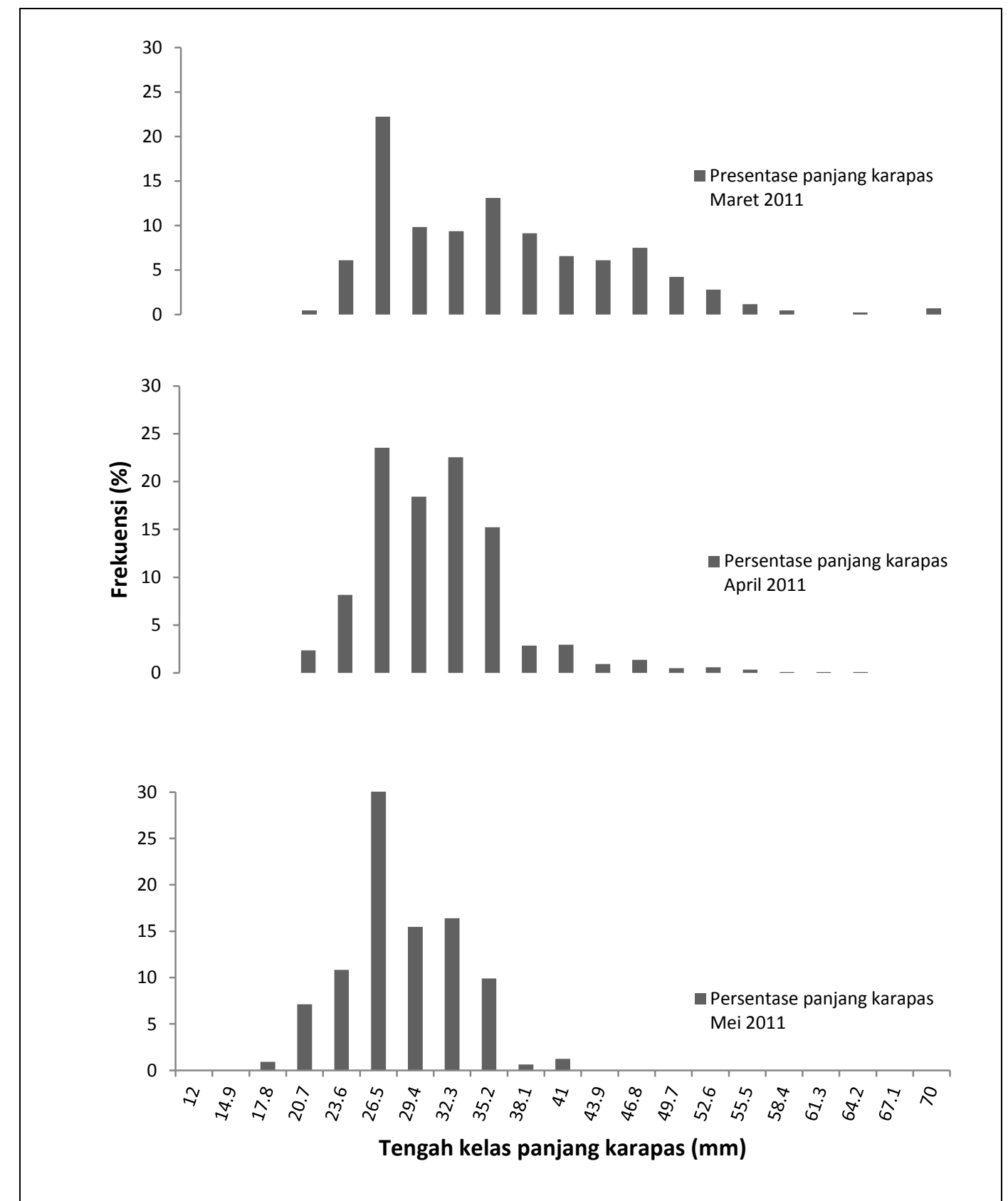

Gambar 4. Sebaran panjang karapas udang Penaeus merguiensis (mm) pada perairan Distrik Naukenjerai Maret-Mei 2011 


\section{DAFTAR PUSTAKA}

Ayub $Z$ and M. Ahmed., 2002. A description of the ovarian development stages of penaeid shrimps from the coast of Pakistan. http://onlinelibrary.wiley.com. (diakses tanggal 6 Desember 2010).

Catherine M. Dichmont., 2006. Management strategies for an input Controlled Fishery Based on the Capture of short-lived tropical species: the example of Australia's Northern Prawn Fishery. The University Of Tasmania

Dinas Kelautan dan Perikanan, 2010. Laporan Tahunan 2009 Pemerintah Kabupaten Merauke: Merauke.

Motoh, H. 1981. Studies on the fisheries biology of the giant tiger prawn, P. monodon, in the Philippines. Tech. Report No. 7, SEAFDEC, Philippines. 128 p.

Nazir., 2003. Metode Penelitian. Cetakan Kelima, Penerbit Ghalia Indonesia.

Peraturan Menteri Kelautan Dan Perikanan Republik Indonesia Nomor Per.02/Men/2011 Tentang Jalur Penangkapan Ikan Dan Penempatan Alat Penangkapan Ikan Dan Alat Bantu Penangkapan Ikan Di Wilayah Pengelolaan Perikanan Negara Republik Indonesia. infohukum.kkp.go.id/files_permen.(diakses pada tanggal 6 Juli 2011).

Simone Valle de Souza, Cedric Gondro, and Oscar Cacho., 2010. An Optimization Model for the Banana Northern Prawn Fishery. University of New England, Australia.

Treece. G. D. 2005. Shrimp maturation and spawning. http://www.lib.noaa.gov/ iapan/aquaculture/proceedinqs/report28/Treece.pdf.(Diakses tanggal 20 Januari 2011).

Udupa, K.S. 1986. Statistical Method of Estimating the size at first maturity in Fishes. Fishbyte 4(2) : 8-10.

Wonglapsuwan Monwadee, Teruo Miyazaki, Wiriya Loongyai and Wilaiwan Chotigeat., 2010. Characterization and Biological Activity of the Ribosomal Protein L10a of the White Shrimp: Fenneropenaeus merguiensis De Man During Vitellogenesis. Mar Biotechnol (2010) 12:230-240. 